\title{
INFLUENCE OF CYCLIC FREEZING AND THAWING ON THE HYDRAULIC CONDUCTIVITY OF SELECTED AGGREGATES USED IN THE CONSTRUCTION OF GREEN ROOFS
}

\author{
Karolina Gwóżdź', Edyta Aleksandra Hewelke², Stanisław Żakowicz', Wojciech Sas², Anna Baryła \\ 1 Department of Environmental Improvement, Faculty of Civil and Environmental Engineering, Warsaw \\ University of Life Sciences - SGGW, Nowoursynowska 159, 02-776 Warsaw, Poland \\ 2 Laboratory - Water Centre, Faculty of Civil and Environmental Engineering, Warsaw University of Life Sciences \\ -SGGW, ul. Ciszewskiego 6, 02-776 Warsaw, Poland, e-mail: edyta_hewelke@sggw.pl
}

Received: 2016.06.06 Accepted: 2016.08.10 Published: 2016.09 .20

\begin{abstract}
The construction of a green roof requires drainage which ought to be characterized by adequate hydraulic conductivity and be resistant to changing meteorological conditions during the winter period. A properly functioning drainage system guarantees the reliability of the entire green roof system. The article presents studies on the freeze-thaw durability and hydraulic conductivity of selected aggregates applied for constructing green roof drainage systems. The aggregates were subjected to a cyclic freezing and thawing process in 30 and 70 cycles. The obtained results indicate that the conductivity of aggregates studied using the constant head method decreases along with an increase in the number of freeze-thaw cycles they were subjected to. This means that the indicator of freeze-thaw durability can have an indicative nature in the assessment of the usefulness of selected aggregates for constructing drainage layers. The conducted studies indicate that the deciding parameter when selecting an aggregate ought to be its hydraulic conductivity, determined accounting for the changes taking place in the freeze-thaw cycles. The equations of changes in the conductivity of aggregates indicated by the authors make it possible to assess them for practical purposes.
\end{abstract}

Keywords: aggregates, freeze-thaw durability, hydraulic conductivity, green roofs

\section{INTRODUCTION}

Green roofs are used more and more often in the construction of buildings, comprising an interesting element of architecture, as well as a solution for helping regulate the heat balance on the inside and outside of a building, and water balance of urban catchments. A green roof also means the better usage of space, especially in large city development. In addition to their ecologic values, green roofs fulfill esthetic and social needs and are an increasingly significant economic factor in shaping the environment of urbanized areas. Their versatility results in facilitating the sustainable development of urban space, supplementing traditional technological solutions [i.a. Getter \& Rowe 2006, Oberndorfer et al. 2007, Kowalczyk 2011, Zhao \& Srebric 2012, Małuszyńska et. al.
2014, Van Mechelen et al. 2015, Nnaemeka-Okeke 2016]. The increasing popularity of green roofs is connected with the dynamic development of studies on constructions and technologies continuously aiming to increase their reliability, durability and safety, as well as the effective use of water, energy and space [i.a. Berndtsson 2010, D'Orazio et al. 2012, Szajda-Brinfeld et al. 2012, Karczmarczyk et al. 2014, Nawaz et al. 2015, Zhang et al. 2015]. A significant element of a green roof is a drainage system for removing excess water. The drainage should be characterized by adequate hydraulic conductivity and be resistant to the changing metrological conditions during the winter period. The article presents the results of studies on freeze-thaw durability and hydraulic conductivity of selected aggregates applied in the construction of green roof drainage systems. 


\section{STUDY AIM AND METHODOLOGY}

The aim of the study is to determine the influence of cyclic freezing and thawing on the destruction and hydraulic conductivity of aggregates used in the construction of green roofs. The drainage layer (Figure 1) is made of mineral aggregates of a natural (i.a. gravel and crushed stone) and artificial (light expanded clay aggregate - LECA) origin, as well as those obtained from recycling (i.a. brick, rubble).

Some of these materials are also used as components of substrates. Six aggregates that can be used in the drainage layer were subjected to analysis (Figure 2, Table 1).
The main aim of the drainage layer is to remove excess water. Properly carried out drainage systems ensure long-term, safe and failure-free functioning of a green roof. Restricting the ability to remove water from the drainage layer leads to excessive moisture content of the substrate and failure of the system. A characteristic property of aggregates applied in the construction of green roofs is their high water absorbability, reaching as much as $20 \%$ (Table 1 ). This ensures the possibility of retaining water by the drainage layer and its redistribution to the plant root zone (substrate) during periods of draught. On the other hand, the high absorbability can have an unfavorable effect on the freeze-thaw durability of aggregates [stan-

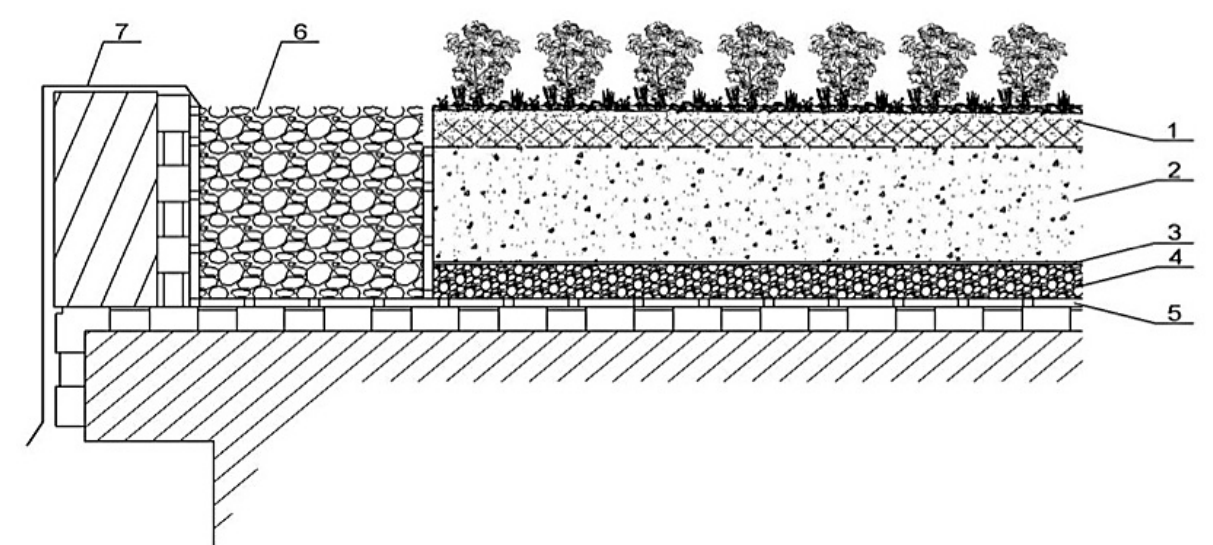

Figure 1. The drainage layer in green roof structure. 1 - plant cover, 2 - vegetation-storage layer, 3 - separating layer, 4 - drainage layer, 5 - waterproofing layer, 6 - peripheral drainage, 7 - metal profile

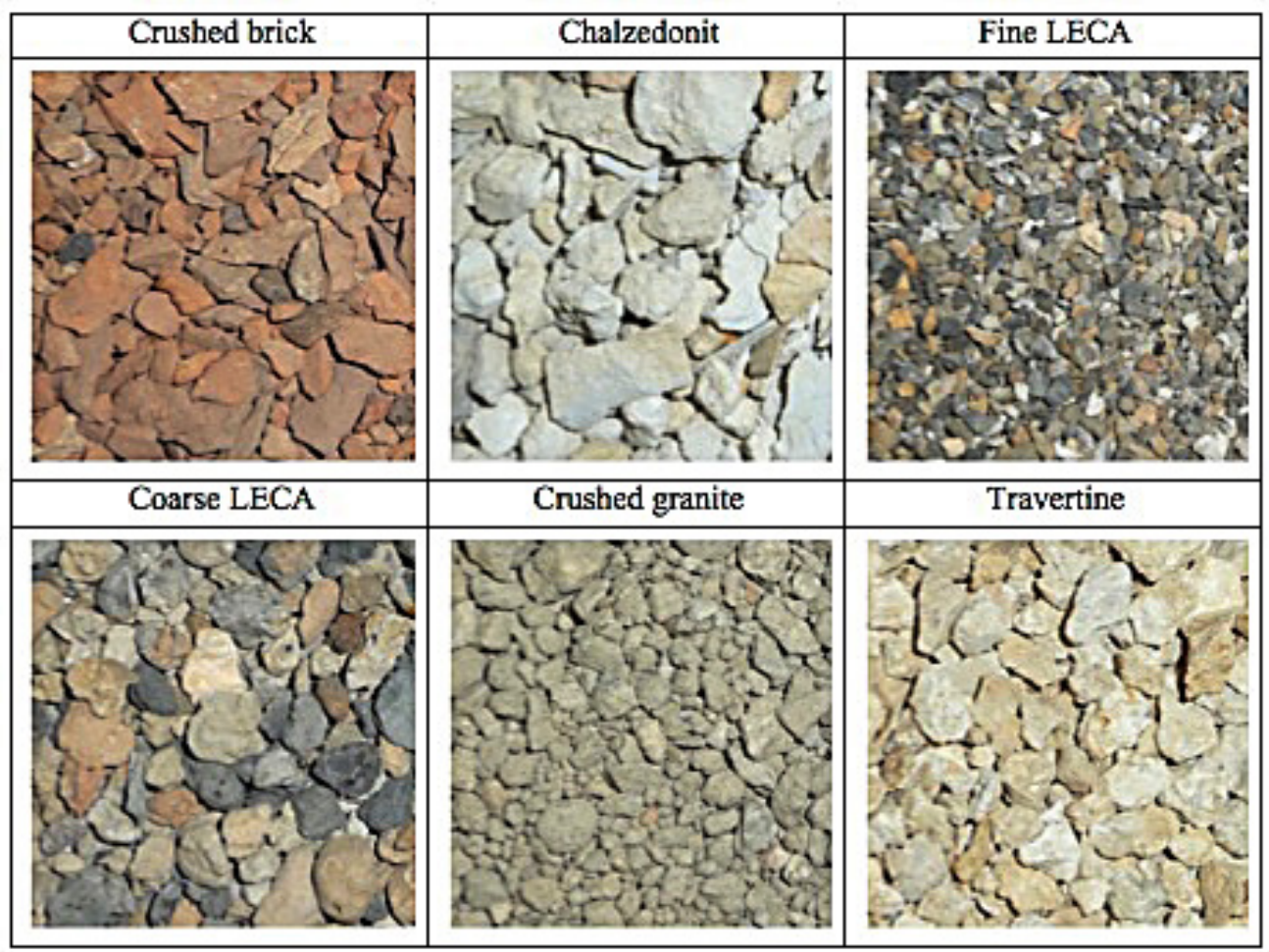

Figure 2. Analyzed aggregates used in the drainage of green roofs 
Table 1. Average density and absorbability of analyzed aggregates (www.gcl.com.pl)

\begin{tabular}{|l|c|c|c|}
\hline \multicolumn{1}{|c|}{ Aggregate } & Fraction $[\mathrm{mm}]$ & Density $\left[\mathrm{kg} \cdot \mathrm{m}^{-3}\right]$ & Absorbability [\%] \\
\hline Crushed brick & $1-16$ & 1350 & 17.5 \\
Chalzedonit & $1-16$ & 1150 & 20 \\
Fine LECA & $\leq 4$ & 750 & 10 \\
Coarse LECA & $3-10$ & 750 & 10 \\
Crushed granite & $\leq 8$ & 1900 & 10 \\
Travertine & $2-12$ & 1600 & 10 \\
\hline
\end{tabular}

dards PN-EN 1977-6:2013-11]. It is generally believed that absorbability not exceeding $1 \%$ guarantees high free-thaw durability of aggregates. In the case of some limestone, sandstone and slag, as well as aggregates derived from ceramic waste products, values of absorbability are higher, while the aggregates are durable enough to use in the production of concrete [Góralczyk \& Kukielska 2010, Gawenda et al. 2013].

The offer of various kinds of drainage mats and plates made from HDPE or PCV materials, characterized by low mass and high water retention, is also developing dynamically [i.a. Szajda-Brinfeld et al. 2012]. However, both solutions are alternatively applied in practice, and in many points of the system, drainage applying aggregates is irreplaceable. In connection with the above, aggregates should fulfill specific criteria, especially in terms of their durability and hydraulic conductivity. Aggregates in the construction of green roofs are susceptible to a high range of temperatures, especially cyclic changes from positive to negative temperatures. The change in water density under such conditions is significant, which causes, among others, the flaking, cracking and crumbling of the material. A measure of the resistance of a material to the damaging effect of water freezing in its pores is its freeze-thaw durability. Such durability of single-fraction aggregate is, according to the standards PN-EN 1367-1:2007, indicated as the mass loss of a sample subjected to cyclic freezing-thawing, and is expressed by the formula:

$$
F=\frac{M_{1}-M_{2}}{M_{1}} \cdot 100 \%
$$

where: $M_{1}$ - initial total mass of dried study samples [g],

$M_{2}$ - final total mass of dried study samples, as remaining on a sieve with openings measuring half the lower measurement of the sieve used for preparing the study samples [g],
$F$ - mass loss of study samples following cyclic freeze-thawing [\%].

For aggregates of varying fractions, the freezethaw durability $F$ is calculated as the weighted average of the results of freeze-thaw durability of individual fractions of the analyzed aggregate [Gantner et al. 2000]. The study of freeze-thaw durability of aggregates were carried out in a ToRoPol chamber (Figure 3). The time of one test cycle of freezing to a temperature to $-20^{\circ} \mathrm{C}$ and thawing to a temperature of $20^{\circ} \mathrm{C}$ was 6 hours and $45 \mathrm{~min}$. The study of freeze-thaw durability was carried out after 30 freeze-thaw cycles. Crushed granite and fine LECA, as they are fine aggregates, were excluded from freeze-thaw durability testing.

The second analyzed property of aggregates was hydraulic conductivity. The standard for geotechnical investigations [PKN-CEN ISO/TS 17892-11] and the Technical Requirements for blends unbound [GDDKiA, 2010, Annex 3 to the Ordinance 102] were included in the research methodology of the coefficient of hydraulic conductivity. The laboratory method of constant head was applied for measuring hydraulic conductivity [Pisarczyk 2004, Pisarczyk 2012] calculating the value of the coefficient of hydraulic conductivity from the following dependency:

$$
k_{T}=\frac{Q}{\text { Fit }}
$$

where: $k_{T}$ - coefficient of hydraulic conductivity measured at a temperature $\mathrm{T}^{\circ} \mathrm{C}\left[\mathrm{cm} \cdot \mathrm{s}^{-1}\right]$, $Q$ - volume of water flowing through the analyzed sample in time $\mathrm{t}\left[\mathrm{cm}^{3}\right]$,

$F$ - cross-sectional area of the analyzed sample $\left[\mathrm{cm}^{2}\right]$,

$i$ - hydraulic gradient [-],

$t$ - time of water flowing through the analyzed sample [s].

The water conductivity of aggregates was tested in three repetitions, i.e. prior to freezing and after 30 and 70 freeze-thaw cycles. 


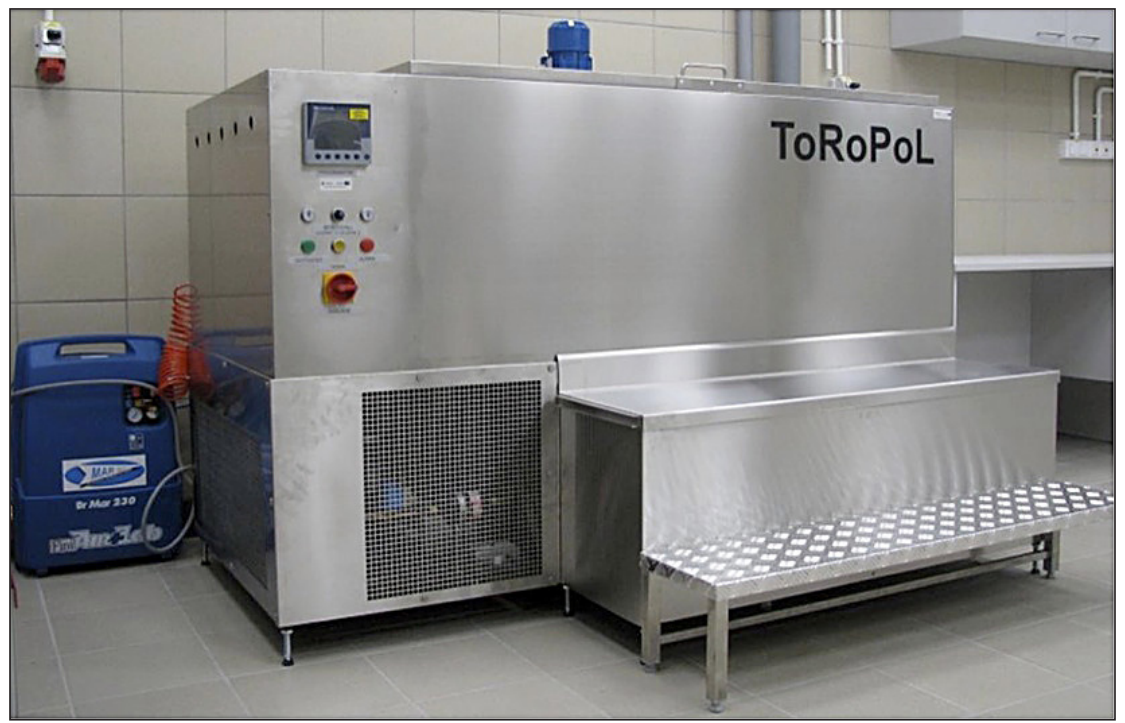

Figure 3. Chamber for assessing freeze-thaw durability

\section{STUDY RESULTS}

The results of studies on freeze-thaw durability presented in Figure 4 indicate travertine to be the most resistant to freezing and thawing. The loss of mass following 30 freeze-thaw cycles amounted to merely $F=3.88 \%$. The lowest resistance to the effects of changes in the density of water was exhibited by crushed brick, indicating a 7.82\% loss of mass. The mass losses of Chalzedonit and coarse LECA were 4.27 and $5.82 \%$ respectively.

The results of measurements of the coefficient of hydraulic conductivity have been presented in Table 2. Coarse LECA was characterized by the

Table 2. Average values of coefficient of hydraulic conductivity k10 depending on the number of freeze-thaw cycles for individual aggregates $\left[\mathrm{cm} \cdot \mathrm{s}^{-1}\right]$

\begin{tabular}{|l|c|c|c|c|c|}
\hline \multirow{2}{*}{ Aggregate } & \multicolumn{2}{|c|}{ Coefficient of hydraulic conductivity $\mathrm{k}_{10}\left[\mathrm{~cm}^{*} \mathrm{~s}^{-1}\right]$} & \multicolumn{2}{c|}{ Decrease in value $\mathrm{k}_{10}[\%]$} \\
\cline { 2 - 6 } & prior to freezing & after 30 cycles & after 70 cycles & after 30 cycles & after 70 cycles \\
\hline Crushed brick & 2.124 & 1.855 & 1.105 & 13 & 48 \\
Chalzedonit & 4.310 & 3.102 & 2.148 & 28 & 50 \\
Fine LECA & 0.457 & 0.329 & 0.267 & 28 & 42 \\
Coarse LECA & 6.360 & 2.111 & 0.918 & 67 & 86 \\
Crushed granite & 0.043 & 0.027 & 0.011 & 40 & 74 \\
Travertine & 0.993 & 0.797 & 0.664 & 0 & 33 \\
\hline
\end{tabular}

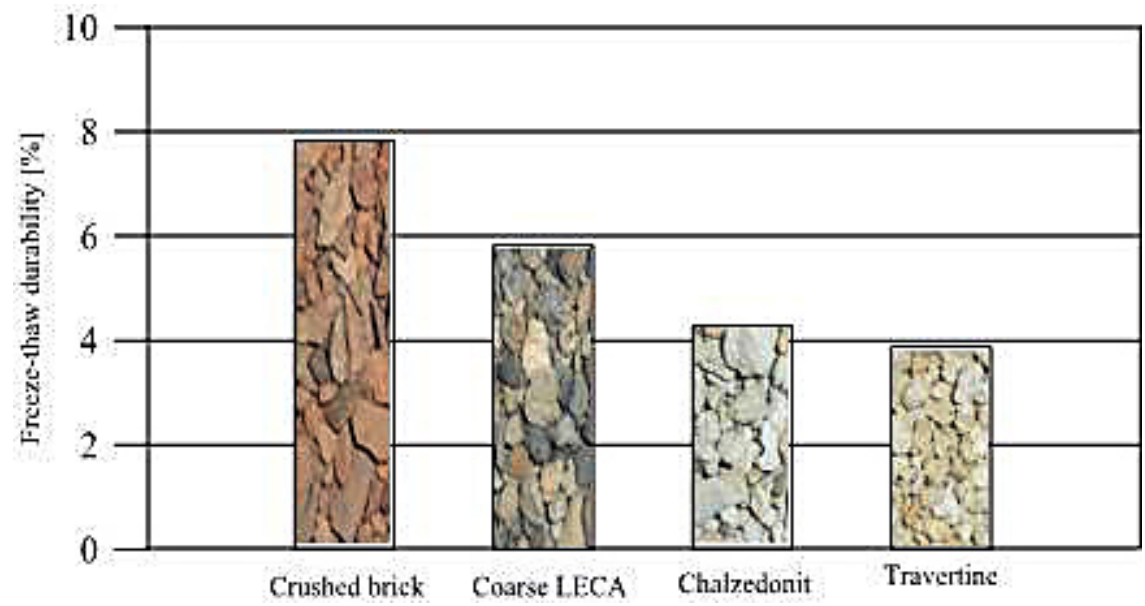

Figure 4. Freeze-thaw durability of analyzed aggregates 
highest hydraulic conductivity prior to freezing $\left(\mathrm{k}_{10}=6.36 \mathrm{~cm} \cdot \mathrm{s}^{-1}\right)$. The lowest value, i.e. $\mathrm{k}_{10}=$ $0.043 \mathrm{~cm} \cdot \mathrm{s}^{-1}$, was determined for crushed granite aggregate. After 70 freeze-thaw cycles, Chalzedonit was characterized by the highest value, i.e. $\mathrm{k}_{10}=2.148 \mathrm{~cm} \cdot \mathrm{s}^{-1}$, with the lowest noted for crushed granite.

All aggregates expressed a decrease in conductivity along with an increase in the number of freeze-thaw cycles.

The lowest decrease in the value of the coefficient of hydraulic conductivity after 30 freezethaw cycles (13\%) was noted in crushed brick, at the same time indicating the lowest freeze-thaw durability $(\mathrm{F}=7.82 \%)$. This means that the freezethaw durability $\mathrm{F}$ can only serve as an additional indicator when selecting aggregates for the construction of green roofs. A reliable parameter determining their usefulness is hydraulic conductivity. In the conducted studies, the highest value of the coefficient of hydraulic conductivity after 70 free-thaw cycles was noted for Chalzedonit $\left(\mathrm{k}_{10}=\right.$ $\left.2.148 \mathrm{~cm} \cdot \mathrm{s}^{-1}\right)$, with the lowest for crushed granite $\left(\mathrm{k}_{10}=0.011 \mathrm{~cm} \cdot \mathrm{s}^{-1}\right)$ and LECA $\left(0.267=\mathrm{cm} \cdot \mathrm{s}^{-}\right.$ $\left.{ }^{1}\right)$. Considering German FLL recommendations [FLL, 2008] that the lowest acceptable value of $\mathrm{k}_{10}$ for aggregates applied in the drainage systems of green roofs should be no less than $0.3 \mathrm{~cm} \cdot \mathrm{s}^{-1}$, such a condition was not fulfilled by the crushed granite even prior to freezing $\left(\mathrm{k}_{10}=0.043 \mathrm{~cm} \cdot \mathrm{s}^{-1}\right)$ or fine LECA after 70 freeze-thaw cycles $\left(\mathrm{k}_{10}=0.267\right.$ $\left.\mathrm{cm} \cdot \mathrm{s}^{-1}\right)$. This means that the above-mentioned aggregates are not suitable for being used as the sole, homogeneous drainage layer of a green roof.
The change of temperatures from $-20^{\circ}$ to $+20^{\circ} \mathrm{C}$ over the course of the study in accordance with the standards PN-EN-1367-1:2007 results in the destruction of aggregate, but does not reflect the actual conditions that exist on a green roof. The change in water density in the range from $-20^{\circ} \mathrm{C}$ do $0^{\circ} \mathrm{C}$ will be equal to 6.185 $\mathrm{kg} \cdot \mathrm{m}^{-3}$. In central Poland, the number of days during which $\mathrm{t}_{\text {min }}<0^{\circ} \mathrm{C}$ and $\mathrm{t}_{\text {max }}>0^{\circ} \mathrm{C}$ is $65-85$ days [Richling and Ostaszewska 2005]. Assuming that the average daily temperature on a green roof is $0^{\circ} \mathrm{C}$, an average $t_{\min }=-3^{\circ} \mathrm{C}$ and average $\mathrm{t}_{\max }=+3^{\circ} \mathrm{C}$ [Kuchcik and Baranowski 2011], the change of $\mathrm{w}=$ ater density in the range from $-3^{\circ} \mathrm{C}$ to $0^{\circ} \mathrm{C}$ will be $0.289 \mathrm{~kg} \cdot \mathrm{m}^{3}$. Assuming that the destructive effect of below-zero temperatures is proportional to the changes in water density, one test cycle is 21.4 times more destructive than the above-assumed transition to below $0^{\circ} \mathrm{C}$ in natural conditions. Assuming that there are 85 such changes annually, this can indicate that one winter corresponds to 4 test cycles. Taking the above into consideration, the results of studies on the hydraulic conductivity after 30 and 70 test cycles will correspond to values existing in nature after 7.5 and 17.5 years, respectively.

The extrapolation of the decreasing trend for the hydraulic conductivity of aggregates was carried out assuming an exponential course of changes in the coefficient of hydraulic conductivity, Table 3.

The estimated values of the hydraulic conductivity (k) of aggregates as a function of the time (t) of using the green roof (Figure 5) make it possible to assess the time during which they

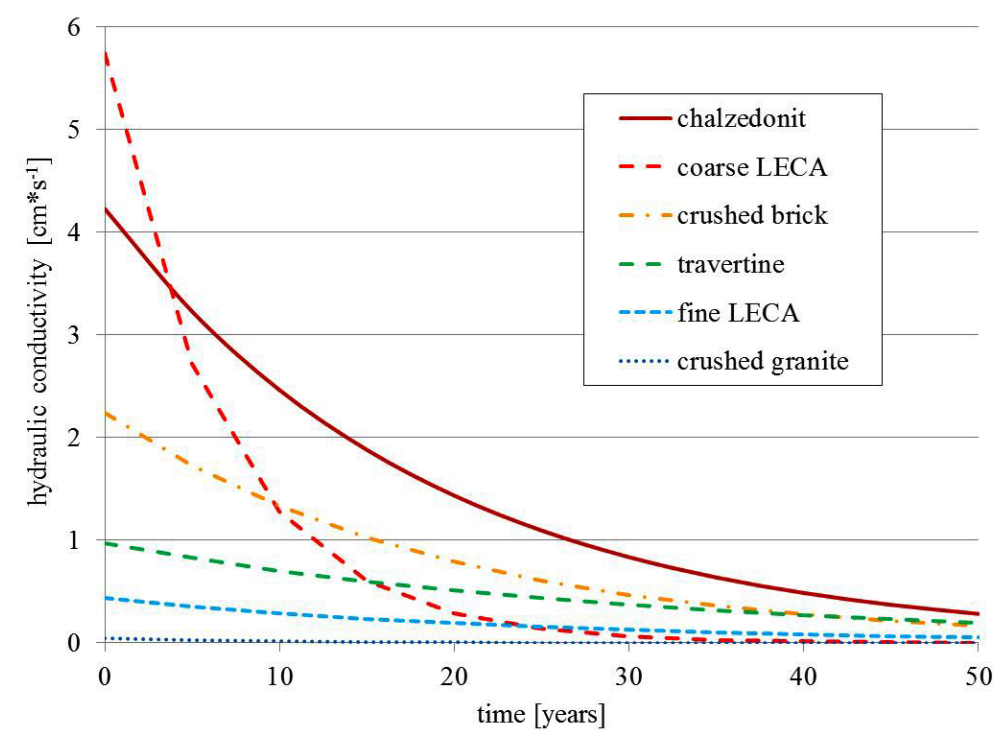

Figure 5. Change in the value of the hydraulic conductivity of aggregates as a function of the time of using the green roof 
Table 3. Equations of the trend of changes in the hydraulic conductivity of aggregates $\left[\mathrm{cm} \cdot \mathrm{s}^{-1}\right]$ depending on the time of use in years

\begin{tabular}{|l|c|c|}
\hline \multicolumn{1}{|c|}{ Aggregate } & Trend line equation & $\begin{array}{c}\text { Determination } \\
\text { coefficient } \mathrm{R}^{2}\end{array}$ \\
\hline Coarse LECA & $\mathrm{y}=5.745 \mathrm{e}^{-0.15 x}$ & 0.9305 \\
\hline Chalzedonit & $\mathrm{y}=4.2256 \mathrm{e}^{-0,054 x}$ & 0.8062 \\
\hline Crushed brick & $\mathrm{y}=2.238 \mathrm{e}^{-0.052 x}$ & 0.8260 \\
\hline Travertine & $\mathrm{y}=0.9696 \mathrm{e}^{-0.032 x}$ & 0.5032 \\
\hline Fine LECA & $\mathrm{y}=0.4375 \mathrm{e}^{-0.041}$ & 0.7355 \\
\hline Crushed granite & $\mathrm{y}=0.0413 \mathrm{e}^{-0,106 x}$ & 0.8546 \\
\hline
\end{tabular}

fulfill the requirements set out by the standards. Exceeding the acceptable value of $\mathrm{k}=0.3 \mathrm{~cm} \cdot \mathrm{s}^{-1}$ by fine LECA will take place after just 12 years of use, and for coarse LECA - after 20 years. In the case of travertine, this period is 37 years, whereas for crushed brick and Chalzedonit - 39 and 49 years respectively.

\section{CONCLUSIONS}

1. Among the analyzed aggregates, travertine was characterized by the highest freeze-thaw durability $\mathrm{F}=3.88 \%$. Crushed brick was the least resistant to cyclic freezing and thawing with $\mathrm{F}=7.82 \%$.

2. The highest hydraulic conductivity prior to freezing was noted for coarse LECA $\mathrm{k}_{10}=$ $6.4 \mathrm{~cm} \cdot \mathrm{s}^{-1}$, Chalzedonit $\mathrm{k}_{10}=4.3 \mathrm{~cm} \cdot \mathrm{s}^{-1}$, and crushed brick $\mathrm{k}_{10}=2.1 \mathrm{~cm} \cdot \mathrm{s}^{-1}$, whereas crushed granite did not attain the value of $0.3 \mathrm{~cm} \mathrm{~s}^{-1} \mathrm{re}-$ quired by the standard.

3. Following 70 freeze-thaw cycles, the highest decrease in hydraulic conductivity was exhibited by coarse LECA (almost 7 -fold). Travertine exhibited the highest stability, whereas fine LECA was shown to have a lower hydraulic conductivity than that permissible by the standard.

4. The analysis of the trend of changes in the coefficient of hydraulic conductivity indicates that exceeding the permissible value $\left(\mathrm{k}_{10}=0.3 \mathrm{~cm} \cdot \mathrm{s}^{-}\right.$ $\left.{ }^{1}\right)$ for fine and coarse LECA will take place after 12 and 20 years respectively of the green roof being in service. For the remaining aggregates, this period ranges from 37 to 49 years.

5. The conducted study indicates that when assessing the usefulness of aggregates applied in the construction of green roofs, the freeze-thaw indicator is characterized by only an indicative nature. The deciding parameter in choosing an aggregate is its hydraulic conductivity assessed after 30 and 70 freeze-thaw cycles.

\section{REFERENCES}

1. Berndtsson J.C., 2010. Green roof performance towards management of runoff water quantity and quality: A review. Ecological Engineering, 36, 351-360.

2. D’Orazio M., Di Perna C., Di Giuseppe E., 2012. Green roofs yearly performance: A case study in a highly insulated building under temperate climate. Energy and Buildings, 55, 1619-1627.

3. FLL (Forschungsgesellshaft Landschaftsentwicklung Landschaftsbau) 2008. Guidelines for the planning execution and upkeep of green-roof sites. Forschungsgesellshaft Landschaftsentwicklung Landschaftsbau, Bonn, Niemcy.

4. Gantner E, Wrońska Z., Wędrychowski W., Nicewicz S., 2000. Materiały budowlane $\mathrm{z}$ technologia betonu. Ćwiczenia laboratoryjne. Warszawa: Oficyna Wydawnicza Politechniki Warszawskiej, pp. 268.

5. Gawenda T., Naziemiec Z., Walerak A., 2013. Badania wybranych właściwości kruszyw z odpadów ceramicznych oraz betonu wytworzonego $\mathrm{z}$ ich udziałem. Rocznik Ochrona Środowiska, 15: 2003-2021.

6. Getter L.K., Rowe D.B., 2006. The role of extensive green roofs in sustainable development. HortScience, 41/5, 1276-1285.

7. Góralczyk G., Kukielska D., 2010. Jakość krajowych kruszyw. Górnictwo i Geoinżynieria, 34/4, 211-224.

8. Karczmarczyk A., Baryła A., Bus A. 2014. Effect of P-Reactive Drainage Aggregates on Green Roof Runoff Quality. Water, 6, 2575-2589; doi:10.3390/ w6092575.

9. Kowalczyk A., 2011. Zielone dachy szansą na zrównoważony rozwój terenów zurbanizowanych. Zrównoważony Rozwój - Zastosowania, 2, 66-83.

10. Kuchcik M., Baranowski J., 2011. Różnice termiczne między osiedlami mieszkaniowymi o różnym udziale powierzchni czynnej biologicznie. Prace i Studia Geograficzne, 47, 365-372.

11. Małuszyńska I., Caballero-Frączkowski W., Małuszyński M. 2014. Zielone dachy i zielone ściany jako rozwiązania poprawiające zdrowie środowiskowe terenów miejskich. Inżynieria Ekologiczna 36, 40-52.

12. Nawaz R., McDonald A., Postoyko S., 2015. Hydrological performance of a full-scale extensive green roof located in a temperate climate. Ecological Engineering 82, 66-80. 
13. Nnaemeka-Okeke R. 2016. Ubran sprawl and sustainable city development in Nigieria. Journal of Ecological Engineering. 17/2, 1-11.

14. Oberndorfer E., Lundholm J., Bass B., Coffman R.R., Doshi H., Dunnett N., Gaffin S., Köhler M., Liu K.K.Y. and Rowe B., 2007. Green roofs as urban ecosystems: ecological, structures, functions and services. BioScience, 57/10, 823-833.

15. Pisarczyk S., 2004. Grunty nasypowe. Właściwości geotechniczne i metody ich badania. Oficyna Wydawnicza Politechniki Warszawskiej, pp. 238.

16. Pisarczyk S., 2012. Gruntoznawstwo inżynierskie. Wydawnictwo PWN, Warszawa, pp. 347.

17. Richling A. Ostaszewska K., 2005. Geografia fizyczna Polski. PWN S.A., pp. 380.

18. Szajda-Brinfeld E., Pływaczyk A., Skarżyński D., 2012. Zielone dachy. Zrównoważona gospodarka wodna na terenach zurbanizowanych. Wydawnictwo Uniwersytetu Przyrodniczego we Wrocławiu, Wrocław, pp. 182.

19. Van Mechelen C., Dutoit T., Hermy M., 2015. Adapting green roof irrigation practices for a sustainable future: A review. Sustainable Citis and Society, 19, 74-90.
20. Zhang Q., Miao L., Wang X, Liu D, Zhu L., Zhou B., Sun J., Liu J., 2015. The capacity of greening roof to reduce stormwater runoff and pollution. Landscape and Urban Planning 144, 142-150.

21. Zhao M., Srebric J., 2012. Assessment of green roof performance for sustainable buildings under winter weather conditions. J. Cent. South Univ., 19, 639-644.

22. Mieszanki niezwiązane do dróg krajowych. Wymagania techniczne 4, 2010. Załącznik 3 do zarządzenia 102. GDDKiA, Warszawa.

23. PKN-CEN ISO/TS 17892-11. Badania geotechniczne. Badania laboratoryjne gruntów. Część 11. Badanie filtracji przy stałym i zmiennym gradiencie hydraulicznym. PKN 2009.

24. PN-EN 1367-1:2007. Badania właściwości cieplnych i odporności kruszyw na działanie czynników atmosferycznych. Część I: Oznaczanie mrozoodporności. Polski Komitet Normalizacyjny, Warszawa, pp. 12.

25. PN-EN 1097-6:2013-11. Badania mechanicznych i fizycznych właściwości kruszyw. Część 6: Oznaczanie gęstości ziarn i nasiąkliwości. Polski Komitet Normalizacyjny, Warszawa, pp. 51. 